\title{
Special issue on integrated gasification fuel cell (IGFC) technology
}

\author{
Suping Peng ${ }^{1}$
}

Accepted: 2 July 2021 / Published online: 17 July 2021

(C) The Author(s) 2021

Coal is the primary fossil fuel used globally for electricity generation and chemical products for a long time. However, utilization of coal also results in emissions of $\mathrm{CO}_{2}$ and other pollutants. At present, global climate change due to greenhouse gases, especially $\mathrm{CO}_{2}$, is becoming more and more serious. It is necessary to improve the efficiency of coal power generation and achieve nearly zero $\mathrm{CO}_{2}$ emissions.

Integrated gasification fuel cell (IGFC) systems that combine coal gasification and high-temperature fuel cells, such as Solid Oxide Fuel Cell (SOFC) or Molten Carbonate Fuel Cell (MCFC), are promising technologies because higher power generation efficiency and environmentally friendly is expected that of conventional coal-fired power generation systems.

The goal of the issue is to introduce the progress and prospects of advanced IGFC technology and analyze the efficiency and economic performance of the IGFC plant with $\mathrm{CO}_{2}$ capture. This issue also reviews recent advances in basic research and technological development on the processes of coal gasification and purification technology, SOFC technology and MCFC technology, carbon capture, utilization, and storage technology (CCUS), Solid Oxide Electrolysis Cell (SOEC) technology.

From the perspective of IGFC and IGFC technologies in China (Peng et al. 2021), the development of new technology for coal gasification purification and research on the

Suping Peng

psp@ chinacs.org.cn

1 Research Center of Solid Oxide Fuel Cell, State Key Laboratory of Coal Resource and Safety Mining, China University of Mining and Technology-Beijing,

Beijing 100083, China formation mechanism of pollutants are presented (Zheng et al. 2021). Meanwhile, the effect of alkali metal ions on the formation mechanism of $\mathrm{HCN}$ during pyridine pyrolysis is researched (Liu et al. 2021).

The critical fuel cell technology about the performance test on a $5 \mathrm{~kW}$ SOFC system under high fuel utility with practical syngas feeding(Xu et al. 2021), the operating parameters of the $10 \mathrm{~kW}$ SOFC-CHP system with syngas ( $\mathrm{Li}$ et al. 2021), and $10 \mathrm{~kW}$ molten carbonate fuel cell power generation systems are introduced ( $\mathrm{Lu}$ et al. 2021). In addition, the fabrication and performance of atmospheric plasma sprayed solid oxide fuel cells with liquid antimony anodes are researched (Jiang et al. 2021).

Based on this, key $\mathrm{CO}_{2}$ capture technology for pure oxygen exhaust gas combustion by syngas-fueled hightemperature fuel cells (Wang et al. 2021) and $\mathrm{CO}_{2}$ utilization technology by SOEC technology (Yang et al. 2021) are discussed.

Finally, the status update of the IGFC power generation system being developed at the National Institute of Cleanand-Low-Carbon (NICE) at the $\mathrm{MW}_{\text {th }}$ scale is provided (Wei et al. 2021).

All the studies presented in the Special Issue cover both the development of IGFC technologies and the key result of the IGFC project.

Open Access This article is licensed under a Creative Commons Attribution 4.0 International License, which permits use, sharing, adaptation, distribution and reproduction in any medium or format, as long as you give appropriate credit to the original author(s) and the source, provide a link to the Creative Commons licence, and indicate if changes were made. The images or other third party material in this article are included in the article's Creative Commons licence, unless indicated otherwise in a credit line to the material. If material is not included in the article's Creative Commons licence and your intended use is not permitted by statutory regulation or exceeds the permitted use, you will need to obtain permission directly from the copyright 
holder. To view a copy of this licence, visit http://creativecommons. org/licenses/by/4.0/.

\section{References}

Jiang YD, Mo WF, Cao TY, Shi YX, Cai NS (2021) Fabrication and performance of atmospheric plasma sprayed solid oxide fuel cells with liquid antimony anodes. Int J Coal Sci Technol. https://doi.org/10.1007/s40789-021-00430-8

Li B, Lyu ZW, Zhu JZ, Han MF, Sun ZH (2021) Study on the operating parameters of the $10 \mathrm{~kW}$ SOFC-CHP system with syngas. Int J Coal Sci Technol. https://doi.org/10.1007/s40789021-00451-3

Liu J, Zhao W, Fan XR, Xu MX, Zheng S, Lu Q (2021) Effect of alkali metal ions on the formation mechanism of $\mathrm{HCN}$ during pyridine pyrolysis. Int J Coal Sci Technol. https://doi.org/10. 1007/s40789-021-00427-3

Lu CZ, Zhang RY, Yang GJ, Huang H, Cheng J, Xu SS (2021) Study and performance test of $10 \mathrm{~kW}$ molten carbonate fuel cell power generation system. Int J Coal Sci Technol. https://doi.org/10. 1007/s40789-021-00442-4

Peng SP (2021) Current status of national integrated gasification fuel cell projects in China. Int J Coal Sci Technol. https://doi.org/10. 1007/s40789-021-00443-3
Wang HL, Lei QL, Li PP, Liu CL, Xue YP, Zhang XW, Li CF, Yang $\mathrm{ZB}$ (2021) Key $\mathrm{CO}_{2}$ capture technology of pure oxygen exhaust gas combustion for syngas-fueled high-temperature fuel cells. Int J Coal Sci Technol. https://doi.org/10.1007/s40789-021-00445-1

Wei C, Liu ZE, Li CF, Singh Surinder LuHR, Gong YD, Li PP, Wang HL, Yang X, Xu M, Mu SJ (2021) Status of an MWth integrated gasification fuel cell power-generation system in China. Int $\mathrm{J}$ Coal Sci Technol. https://doi.org/10.1007/s40789-021-00429-1

Xu M, Wang HL, Liu MX, Zhao JN, Zhang YQ, Li PP, Shi ML, Gong SQ, Zhang ZH, Li CF (2021) Performance test of a $5 \mathrm{~kW}$ solid oxide fuel cell system under high fuel utilization with industrial fuel gas feeding. Int J Coal Sci Technol. https://doi.org/10.1007/ s40789-021-00428-2

Yang ZB, Lei Z, Ge B, Xiong XY, Jin YQ, Jiao K, Chen FL, Peng SP (2021) Development of catalytic combustion and $\mathrm{CO}_{2}$ capture and conversion technology. Int J Coal Sci Technol. https://doi. org/10.1007/s40789-021-00444-2

Zheng S, Shi YX, Wang ZQ, Wang PJ, Liu G, Zhou HC (2021) Development of new technology for coal gasification purification and research on the formation mechanism of pollutants. Int $\mathrm{J}$ Coal Sci Technol. https://doi.org/10.1007/s40789-021-00420-w 